\title{
PENGGUNAAN METODE BENEISH RATIO DALAM PENDETEKSIAN KECURANGAN LAPORAN KEUANGAN
}

\author{
Lukas Murdihardjo ${ }^{1}$, Yayuk Nurjanah ${ }^{2}$, Febriani Indah Sari ${ }^{3}$ \\ 1,2,3 Institut Bisnis dan Informatika Kesatuan, yayuknurjanah@ibik.ac.id
}

\begin{abstract}
ABSTRAK
Penelitian ini bertujuan untuk mendeteksi kecurangan terhadap laporan keuangan dengan menggunakan Metode Beneish Rasio Indeks pada Perusahaan Subsektor Makanan dan Minuman yang Listing di Bursa Efek Indonesia. Data yang digunakan dalam penelitian ini adalah data sekunder periode 2015 sampai dengan 2019, yang diperoleh dari website www.idx.com dengan jumlah 12 sampel perusahaan subsektor makanan dan minuman untuk mengetahui perusahaan mana yang tergolong manipulator, non manipulator, dan grey company. Teknik pengambilan data menggunakan metode purposive sampling, dimana penulis hanya mengambil data- data yang sesuai dengan kriteria yang penulis inginkan. Penulis menggunakan teknik analsis data deskriptif kuantitatif dengan menggunakan Beneish Rasio Indeks. Berdasarkan penelitian, pendeteksian ini dapat diselesaikan dengan menggunakan 8 variabel Beneish Ratio Index yaitu DSRI, GMI, AQI, SGI, DEPI, SGAI, LVGI, dan TATA. Dimana hasil dari periode 2015 sampai dengan 2019 menunjukan bahwa ada 1 perusahaan yang terindikasi manipulator, 51 perusahaan non manipulator, dan 8 perusahaan grey company.
\end{abstract}

Kata Kunci : Beneish Rasio Indeks, Kecurangan Laporan Keuangan, Kecurangan

\begin{abstract}
The purpose of this study is to detect fraud in financial statements using the Beneish Ratio Index Method in the Food and Beverage Subsector Companies listed on the Indonesia Stock Exchange. The data used in this study are secondary data for the period 2015 to 2019, which was obtained from the website www.idx.com with a total of 12 samples of food and beverage sub-sector companies to find out which companies are classified as manipulators, nonmanipulators, and gray companies. The data collection technique used purposive sampling method, where the writer only took the data that matched the criteria that the writer wanted. The author uses quantitative descriptive data analysis techniques using Beneish Ratio Index. Based on the research, this detection can be completed using 8 Beneish Ratio Index variables, namely DSRI, GMI, AQI, SGI, DEPI, SGAI, LVGI, and TATA. Where the results from the 2015 to 2019 period show that there is 1 company that is indicated as a manipulator, 51 non manipulator companies, and 8 gray companies.
\end{abstract}

Keywords : Beneish Ratio Index, Financial Report Fraud, Fraud

Naskah diterima : 12-04-2021, Naskah dipublikasikan : 30-04-2021

\section{PENDAHULUAN}

Laporan keuangan disusun dengan tujuan memberikan informasi posisi keuangan, kinerja dan arus kas perusahaan. Menurut PSAK No. 1 (2015: 1) Laporan keuangan adalah penyajian terstruktur dari posisi keuangan dan kinerja keuangan suatu entitas. Tujuan dari Laporan keuangan menurut Pernyataan Standar Akuntansi Keuangan (PSAK) No. $1(2015 ; 3)$ adalah untuk memberikan informasi mengenai posisi keuangan, kinerja keuangan dan arus kas 
entitas yang bermanfaat bagi sebagian besar kalangan pengguna laporan dalam pembuatan keputusan ekonomi.

Kecurangan ( fraud) merupakan bentuk penipuan yang sengaja dilakukan sehingga menimbulkan kerugian tanpa disadari oleh pihak yang dirugikan tersebut dan memberikan keuntungan bagi pelaku kecurangan (Karyono, 2013). Di Indonesia juga banyak ditemui kasus kecurangan laporan keuangan yang dilakukan perusahaan untuk menutupi kekurangan yang terjadi sehingga laporan keuangan menjadi menarik dilihat bagi pembaca dan pengguna laporan keuangan lainnya. Sebagai contoh, kasus Bank Bukopin yang melakukan revisi laporan keuangan selama tiga tahun terakhir yaitu 2015, 2016 dan 2017, diduga perusahaan melakukan modifikasi data kartu kredit yang menyebabkan posisi kredit dan pendapatan berbasis komisi bertambah tidak semestinya. OJK melakukan pemeriksaan dan menemukan bahwa laporan keuangan Bank Bukopin dipermak. (Detik finance, 2018). James dan Tommie (2007) Teori Cressey terdapat tiga kondisi yang selalu hadir dalam tindakan fraud yaitu pressure, opportunity, dan razionalization. Ketiga kondisi tersebut merupakan faktor risiko munculnya kecurangan dalam berbagai situasi.

Penelitian tentang analisis kecurangan laporan keuangan menggunakan Beneish Ratio Index telah banyak dilakukan dengan hasil yang beragam, seperti yang dilakukan oleh Efitasari (2013) pada perusahaan manufaktur yang listing di Bursa Efek Indonesia tahun 2010-2011. Indarti (2019) juga meneliti tentang Analisis Beneish Ratio Index untuk mendeteksi Fraudulent Financial Reporting pada Perusahaan Perbankan Yang Terdaftar Di Bursa Efek Indonesia Periode 2015-2016. Berdasarkan hasil penelitian sebelumnya, hasil dari beberapa penelitian menunjukkan hasil yang berbeda-beda sehingga peneliti ingin meneliti kembali. Namun penelitian ini dilakukan pada perusahaan yang berbeda yaitu pada Perusahaan Subsektor Makanan dan Minuman yang terdaftar pada Bursa Efek Indonesia dan menggunakan periode waktu yang berbeda yaitu tahun 2015 sampai 2019.

Peneliti akan melakukan pendeteksian pada Perusahaan subsektor Makanan dan Minuman yang terdaftar di Bursa Efek Indonesia dengan menggunakan metode Beneish Ratio Index untuk mendeteksi apakah ada aktivitas kecurangan terhadap laporan keuangannya. Dengan menggunakan alat deteksi Beneish akan mengidentifikasi perusahaan publik yang tergolong manipulator, dan non manipulator.

\section{KAJIAN LITERATUR Definisi Kecurangan}

Fraud (kecurangan) merupakan suatu tindakan yang dilakukan dengan sengaja, yang dapat menimbulkan kerugian tanpa disadari oleh pihak yang dirugikan, dan memberikan keuntungan bagi pelaku fraud. Pada dasarnya terdapat dua tipe kecurangan, yaitu eksternal dan internal. Kecurangan eksternal adalah kecurangan yang dilakukan oleh pihak luar terhadap suatu perusahaan/entitas, seperti kecurangan yang dilakukan pelanggan terhadap usaha, wajib pajak terhadap pemerintah. Kecurangan internal adalah tindakan illegal dari karyawan, manajer, dan eksekutif terhadap perusahaan tempat dia bekerja.

\section{Laporan Keuangan}

Menurut Ikatan Akuntan Indonesia (2012:5), Laporan keuangan adalah struktur yang menyajikan posisi keuangan dan kinerja keuangan dalam sebuah entitas. Neraca menunjukan atau menggambarkan jumlah aset, kewajiban dan ekuitas dari suatu perusahaan pada tanggal tertentu. Sedangkan laporan laba rugi memperlihatkan hasil-hasil yang telah dicapai oleh perusahaan serta beban yang terjadi selama periode tertentu, dan laporan perubahan ekuitas 
menunjukan sumber dan penggunaan atau alasan-alasan yang menyebabkan perubahan ekuitas perusahaan (Munawir, 2010:5).

Menurut Pernyataan Standar Akuntansi Keuangan (PSAK) No. 1 (2012:6), laporan keuangan yang lengkap terdiri dari komponen-komponen berikut ini:

1. Laporan posisi keuangan pada akhir periode.

2. Laporan laba rugi komprehensif selama periode.

3. Laporan perubahan ekuitas selama periode.

4. Laporan arus kas selama periode.

5. Catatan atas laporan keuangan, berisi ringkasan kebijakan akuntansi penting dan informasi penjelasan lainnya.

6. Laporan posisi keuangan pada awal periode komparatif yang disajikan.

\section{Kecurangan Laporan Keuangan}

Kecurangan Laporan keuangan menurut ACFE (2010) adalah tindakan yang dilakukan pejabat secara sengaja atas informasi yang material dengan tujuan untuk menutupi kondisi keuangan perusahaan yang sebenarnya dan akan memberikan suatu keuntungan bagi pihak yang melakukan kecurangan. Kecurangan ini dapat bersifat finasial dan non finansial.

Menurut IFAC (2009), kecurangan laporan keuangan dapat dilakukan dengan melakukan tindakan seperti:

1. Manipulasi, pemalsuan, atau perubahan catatan akuntansi, dokumen pendukung dari laporan keuangan yang disusun.

2. Kekeliruan atau kelalaian yang disengaja dalam informasi yang signifikan terhadap laporan keuangan.

3. Melakukan secara sengaja penyalahgunaan prinsip-prinsip yang berkaitan dengan jumlah, klasifikasi, cara penyajian, atau pengungkapan.

\section{Indikasi kecurangan Laporan Keuangan}

Kecurangan merupakan suatu tindakan yang dilakukan secara sengaja dengan penuh kerahasiaan, dengan menyalahgunakan jabatan untuk mengalihkan sumber daya yang telah diambil untuk kepentingan pribadi. Beneish (1999) menyatakan Beneish M-score membantu mengungkapkan perusahaan yang memiliki kemungkinan melakukan fraud terhadap laporan keuangannya. Perusahaan dengan $M$-score tinggi memiliki kemungkinan untuk melakukan fraud. Sebaliknya perusahaan dengan M-score rendah memiliki kemungkinan yang lebih kecil untuk melakukan fraud.

\section{Deteksi Kecurangan Laporan Keuangan}

Salah satu resiko yang dihadapi perusahaan adalah integrity risk, yaitu risiko adanya kecurangan oleh manajemen atau pegawai perusahaan, tindakan ilegal, atau tindakan penyimpangan lainnya yang dapat mengurangi nama baik/reputasi perusahaan di dunia usaha, atau dapat mengurangi kemampuan perusahaan dalam mempertahankan kelangsungan hidupnya. Beneish Ratio Index yang digunakan untuk mendeteksi adanya manipulasi dalam laporan keuangan tersebut antara lain:

\section{Days Sales In Receivables Index (DSRI)}

$$
\text { DSRI }=\frac{\text { Piutang Usaha }(t) / \text { Penjualan }(t)}{\text { Piutang Usaha }(t-1) / \text { Penjualan }(t-1)}
$$

Variabel ini mengukur apakah piutang dan pendapatan seimbang atau tidak (out of balance) dalam dua tahun yang berurutan. Dengan demikian peningkatan jumlah hari penjualan 
dalam piutang dapat diartikan sebagai hasil dari perubahan kebijakan kredit untuk memacu penjualan dalam menghadapi persaingan yang meningkat.

\section{Gross Margin Index (GMI)}

$$
\boldsymbol{G M I}=\frac{\text { Laba Kotor }(t-1) / \text { Penjualan }(t-1)}{\text { Laba } \operatorname{Kotor}(t) / \text { Penjualan }(t)}
$$

Jika GMI lebih dari 1 (satu), maka terjadi penurunan pada gross margin dan bukti adanya sinyal buruk atas perusahaan. Kenaikan GMI mengindikasikan perusahaan menggelembungkan laba. Dengan demikian terdapat hubungan positif antara GMI dan probabilitas terjadinya manipulasi jika kinerja perusahaan menurun.

\section{Asset Quality Index (AQI)}

$$
\boldsymbol{A Q I}=\frac{1-\frac{\operatorname{Aktiva} \operatorname{Lancar}(t)+\operatorname{AktivaTetap}(t)}{\operatorname{Total} \text { Aktiva }(t)}}{1-\frac{\text { Aktiva Lancar }(t-1)+\text { Aktiva Tetap }(t-1)}{\text { Total Aktiva }(t-1)}}
$$

AQI mengukur risiko dari assets pada tahun t terhadap tahun t-1. Jika AQI lebih besar dari 1 (satu), ini mengindikasikan bahwa perusahaan telah secara potensial meningkatkan pengendalian biaya. AQI juga mengukur proporsi dari Total Assets terhadap keuntungan masa depan manakah yang secara potensial kurang pasti.

Sales Growth Index (SGI)

$$
\boldsymbol{S G I}=\frac{\text { Penjualan }(t)}{\text { Penjualan }(t-1)}
$$

SGI dapat memberitahu manakah perusahan yang memasukkan penjualan palsu. Peningkatan dalam SGI menunjukan bahwa terdapat kecenderungan perusahaan melakukan pencatatan pendapatan fiktif untuk mempertimbangkan pertumbuhan normal yang diharapkan pada periode tersebut.

\section{Depreciation Index (DEPI)}

$$
\boldsymbol{D E P I}=\frac{\frac{\text { Depresiasi }(t-1)}{\text { Depresiasi }(t-1)+\text { Aktiva Tetap }(t-1)}}{\frac{\text { Depresiasi }(t)}{\text { Depresiasi }(t)+\text { Aktiva Tetap }(t)}}
$$

Jika DEPI lebih besar dari 1 (satu), mengindikasikan bahwa tingkat dimana aset sedang didepresiasi melambat, yang meningkatkan kemungkinan bahwa perusahaan telah menaikan estimasi assets useful lives atau menerapkan metode baru yaitu peningkatan income. Beneish (1999) memperkirakan terdapat hubungan positif antara DEPI dengan kemungkinan terjadinya manipulasi.

Sales General and Administrative Expenses Index (SGAI)

$$
\boldsymbol{S G A I}=\frac{S G A(t) / \text { Penjualan }(t)}{S G A(t-1) / \text { Penjualan }(t-1)}
$$


SGAI menginterpretasikan bahwa peningkatan yang tidak proporsional dalam penjualan sebagai suatu tanda negatif terhadap prospek perusahaan di masa mendatang. Beneish (1999) memperkirakan terdapat hubungan positif antara SGAI dengan kemungkinan terjadinya manipulasi.

\section{Leverage Index (LVGI)}

$$
\boldsymbol{L V G I}=\frac{\text { Total Kewajiban }(t) / \text { TotalAktiva }(t)}{\text { Total Kewajiban }(t-1) / \text { TotalAktiva }(t-1)}
$$

LVGI yang lebih besar dari 1 (satu), mengindikasikan peningkatan dalam leverage. Variabel ini dimaksudkan untuk menangkap adanya insentif dalam debt covenant yang digunakan untuk memanipulasi pendapatan. Menurut Beneish (1999) perubahan leverage dalam struktur modal sebuah perusahaan dikaitkan dengan pengaruh technical default di bursa saham.

Total Accruals to Total Assets (TATA)

$$
\boldsymbol{T A T A}=\frac{\text { LabaUsaha }(t)-\text { Arus Kas Dari Aktivitas Operasional }(t)}{\text { Total Aktiva }}
$$

Beneish (1999) menggunakan TATA untuk memperkirakan sejauh mana cash mendasari pendapatan yang dilaporkan, dan juga memperkirakan accruals positif yang lebih tinggi (lebih sedikit cash) dikaitkan dengan kemungkinan manipulasi pendapatan yang lebih tinggi.

\section{METODE PENELITIAN}

Subjek yang digunakan dalam penelitian ini adalah perusahaan subsektor makanan dan minuman yang terdaftar di Bursa Efek Indonesia tahun 2015-2019. Penelitian ini dilakukan pada perusahaan subsektor makanan dan minuman di Bursa Efek Indonesia melalui media internet dengan situs resmi www.idx.co.id. Metode yang digunakan dalam penelitian ini adalah metode deskriptif kuantitatif, yaitu suatu metode yang dilakukan dengan cara mencari data yang menggambarkan kinerja keuangan perusahaan, kemudian membandingkannya antara hasil penelitian pada periode tertentu dengan periode lainnya.

Dalam penelitian ini populasi yang digunakan adalah perusahaan subsektor makanan dan minuman yang terdaftar pada Bursa Efek Indonesia pada tahun 2015 sampai dengan 2019 yang berjumlah 12 perusahaan. Dikarenakan populasi yang diteliti berjumlah besar maka diperlukan sampel penelitian agar memudahkan penelitian. Menurut Sugiyono (2009), purposive sampling adalah teknik pengambilan sampel dengan menggunakan pertimbangan/kriteria tertentu.

Data yang digunakan dalam penelitian ini yaitu data sekunder. Data sekunder tersebut berupa laporan keuangan dari perusahaan subsektor makanan dan minuman yang terdaftar pada Bursa Efek Indonesia (BEI) periode 2015-2019 yang diperoleh dari situs pendukung melalui www.idx.co.id. Data yang digunakan adalah laporan keuangan tahunan dari tahun 2015 sampai 2019. 


\section{JURNAL AKUNTANSI, Vol. 10, No. 1, April (2021)}

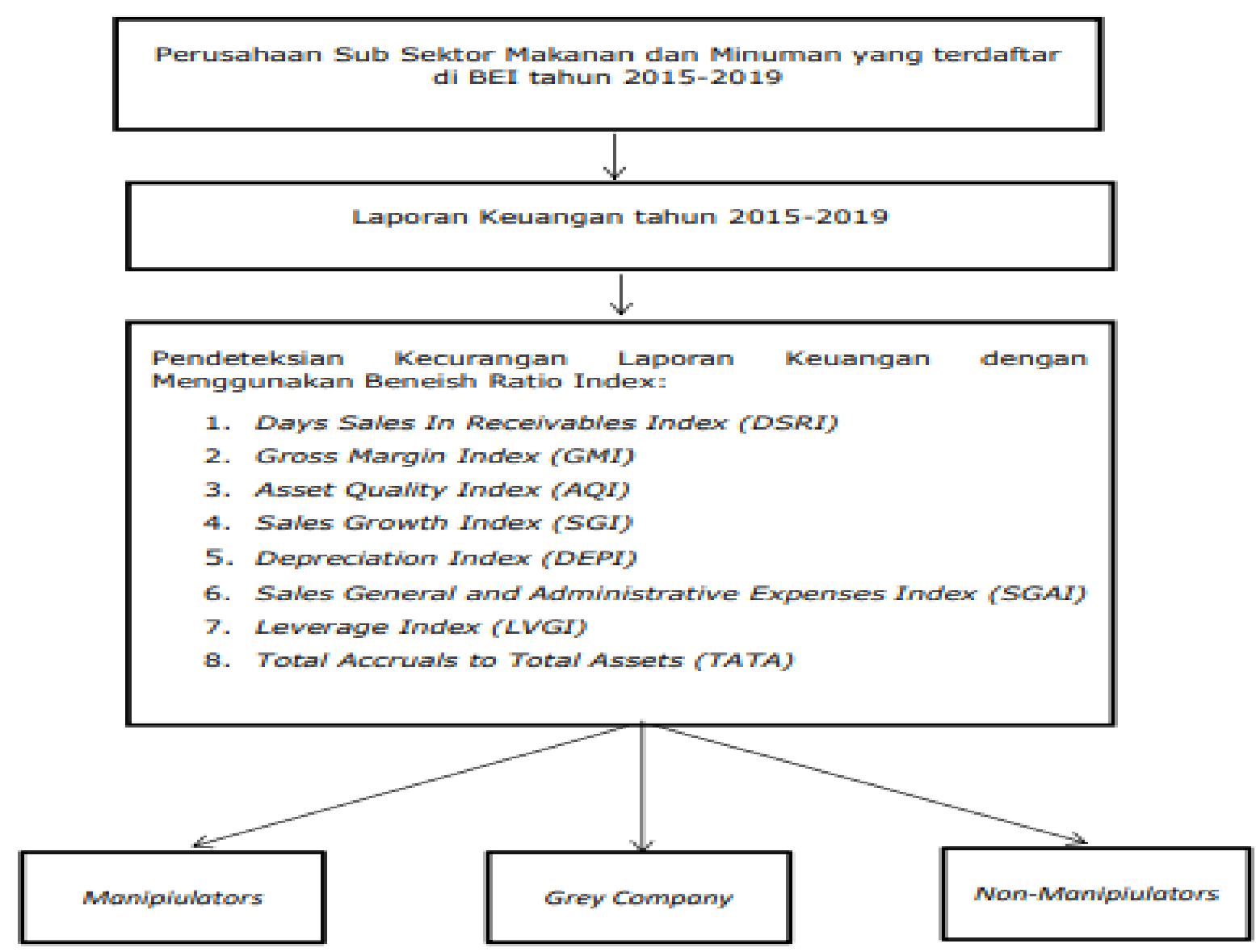

Gambar 1. Kerangka Pemikiran

Teknik pengumpulan data yang digunakan adalah dokumentasi. Teknik ini dilakukan dengan mengumpulkan, mempelajari, dan menganalisis data laporan keuangan perusahaan. Data yang digunakan dalam penelitian ini berupa laporan keuangan perusahaan subsektor makanan dan minuman yang listing di Bursa Efek Indonesia (BEI) tahun 2015-2019. Data diperoleh dari download softcopy laporan keuangan emiten di website Bursa Efek Indonesia (BEI) www.idx.co.id. Penyusun juga menggunakan purposive sampling dimana penyusun hanya mengambil data-data yang sesuai dengan kriteria yang peneliti inginkan.

Analisis data merupakan salah satu proses penelitian yang dilakukan setelah semua data yang diperlukan untuk memecahkan permasalahan yang diteliti sudah diperoleh secara lengkap. Penelitian ini menggunakan teknik analisis Ratio Index terhadap data laporan keuangan perusahaan yang menjadi sampel. Perhitungan ratio index dimaksudkan untuk menentukan kategori suatu perusahaan tergolong manipulators atau non manipulators. Perusahaan dikategorikan tergolong manipulators atau non manipulators apabila memperoleh nilai ratio index sesuai dengan indeks parameter menurut Beneish Model. 


\section{JURNAL AKUNTANSI, Vol. 10, No. 1, April (2021)}

\section{HASIL DAN PEMBAHASAN \\ Gambaran Umum Sampel Perusahaan \\ Deskripsi Objek Penelitian}

Data penelitian ini menggunakan populasi perusahaan subsektor makanan dan minuman yang terdaftar di Bursa Efek Indonesia (BEI) tahun 2015-2019. Data yang berhasil menjadi sampel pada penelitian ini adalah sebanyak 12 perusahaan subsektor makanan dan minuman dengan total data 60 laporan tahunan perusahaan. Perusahaan subsektor makanan dan minuman tersebut telah terdaftar di BEI selama periode penelitian.

\section{Proses Seleksi Sampel}

Pengambilan sampel dalam penelitian ini menggunakan metode purposive sampling. Adapun kriteria sampel yang dipilih pada penelitian ini adalah:

Tabel 1. Kriteria Penentuan Sampel

\begin{tabular}{|c|l|c|}
\hline No. & \multicolumn{1}{|c|}{ Kriteria Penentuan Sampel } & Jumlah \\
\hline 1. & Perusahaan subsektor makanan dan minuman & 26 \\
\hline 2. & Data tidak tersedia dengan lengkap & $(14)$ \\
\hline \multicolumn{2}{|c|}{ Jumlah perusahaan yang dapat dijadikan sampel } & 12 \\
\hline & Jumlah sampel 12 perusahaan x 5 tahun (2015-2019) & 60 \\
\hline
\end{tabular}

\section{Hasil Analisis Data}

Subjek pada penelitian ini adalah perusahaan subsektor makanan dan minuman yang terdaftar di BEI tahun 2015-2019. Berdasarkan kriteria sampel yang ditentukan, diperoleh 12 perusahaan yang sesuai dengan kriteria. Berdasarkan data laporan keuangan dari 12 perusahaan, maka selanjutnya dilakukan perhitungan ratio index (indeks hitung) terhadap masing-masing perusahaan tersebut. Hasil perhitungan ratio index tersebut selanjutnya disesuaikan dengan indeks parameter menurut Beneish Model. Perhitungan ini dimaksudkan untuk menentukan kategori dari suatu perusahaan, apakah perusahaan tersebut tergolong perusahaan manipulators, non manipulators atau Grey Company.

Langkah-langkah yang dilakukan untuk menentukan apakah perusahaan tergolong manipulators, non manipulators dan Grey Company adalah sebagai berikut :

a. Menghitung rasio index perusahaan dengan rumus Beneish $M$-Score

b) Membandingkan indeks hitung dengan indeks parameter (Beneish Ratio Index).

c) Menentukan perusahaan tergolong manipulators atau non manipulators menurut kriteria penggolongan.

1. Perusahaan yang memiliki $\geq 3$ (tiga) indeks hitung yang sesuai dengan indeks parameter yang menyatakan Manipulators, tergolong ke dalam perusahaan Manipulators.

2. Perusahaan yang memiliki $\geq 3$ (tiga) indeks hitung yang sesuai dengan indeks parameter yang menyatakan Non Manipulators,tergolong ke dalam perusahaan Non Manipulators.

3. Perusahaan yang memiliki $\geq 3$ (tiga) indeks hitung yang sesuai dengan indeks parameter yang menyatakan grey, dan indeks hitung yang tidak memenuhi 2 (dua) kriteria penggolongan tersebut (Manipulators dan Non Manipulators) digolongkan perusahaan grey (Grey Company). 


\section{JURNAL AKUNTANSI, Vol. 10, No. 1, April (2021)}

Berdasarkan hasil perhitungan 8 rasio index terhadap 12 perusahaan sampel maka dapat disimpulkan kategori perusahaan yang akan dijelaskan dalam tabel berikut :

\section{Days Sales in Receivables Index (DSRI)}

Dari hasil perhitungan Index diketahui hasil dari DSRI dan penentuan kategori dijelaskan dalam tabel berikut:

Tabel 2. Hasil Perhitungan DSRI dan Kategori Perusahaan

\begin{tabular}{|c|c|c|c|c|c|c|c|c|c|c|c|}
\hline \multirow{2}{*}{ No } & \multirow{2}{*}{ Kode } & \multicolumn{2}{|c|}{2015} & \multicolumn{2}{|c|}{2016} & \multicolumn{2}{|c|}{2017} & \multicolumn{2}{|c|}{2018} & \multicolumn{2}{|c|}{2019} \\
\hline & & DSRI & Kategori & DSRI & Kategori & DSRI & Kategori & DSRI & Kategori & DSRI & Kategori \\
\hline 1 & AISA & 1,2588 & G & 1,1110 & $\mathrm{G}$ & 1,1752 & G & 0,5794 & $\mathrm{~N}$ & 1,0590 & $\mathrm{G}$ \\
\hline 2 & ALTO & 0,9059 & $\mathrm{~N}$ & 0,9372 & $\mathrm{~N}$ & 0,8368 & $\mathrm{~N}$ & 1,0789 & $\mathrm{G}$ & 0,7644 & $\mathrm{~N}$ \\
\hline 3 & CEKA & 0,8771 & $\mathrm{~N}$ & 0,9191 & $\mathrm{~N}$ & 0,9924 & $\mathrm{~N}$ & 1,1733 & $\mathrm{G}$ & 1,4377 & $\mathrm{G}$ \\
\hline 4 & DLTA & 0,9288 & $\mathrm{~N}$ & 2,0316 & $\mathrm{M}$ & 0,9810 & $\mathrm{~N}$ & 0,9365 & $\mathrm{~N}$ & 1,3541 & $\mathrm{G}$ \\
\hline 5 & ICBP & 1,1161 & $\mathrm{G}$ & 1,0745 & $\mathrm{G}$ & 1,0043 & $\mathrm{~N}$ & 0,9885 & $\mathrm{~N}$ & 0,8908 & $\mathrm{~N}$ \\
\hline 6 & INDF & 1,1884 & G & 1,0426 & $\mathrm{G}$ & 1,0367 & $\mathrm{G}$ & 1,0250 & $\mathrm{~N}$ & 0,9590 & $\mathrm{~N}$ \\
\hline 7 & MLBI & 0,6086 & $\mathrm{~N}$ & 1,1298 & $\mathrm{G}$ & 1,8803 & $\mathrm{G}$ & 1,0251 & $\mathrm{~N}$ & 1,3687 & $\mathrm{G}$ \\
\hline 8 & MYOR & 1,0572 & G & 1,0463 & $\mathrm{G}$ & 1,1602 & $\mathrm{G}$ & 0,6984 & $\mathrm{~N}$ & 0,9840 & $\mathrm{~N}$ \\
\hline 9 & ROTI & 1,0080 & $\mathrm{~N}$ & 0,9722 & $\mathrm{~N}$ & 1,1732 & $\mathrm{G}$ & 1,1444 & $\mathrm{G}$ & 0,9668 & $\mathrm{~N}$ \\
\hline 10 & SKLT & 0,9978 & $\mathrm{~N}$ & 1,1144 & $\mathrm{G}$ & 0,9988 & $\mathrm{~N}$ & 1,2292 & $\mathrm{G}$ & 0,8789 & $\mathrm{~N}$ \\
\hline 11 & STTP & 0,9500 & $\mathrm{~N}$ & 1,2093 & $\mathrm{G}$ & 0,9541 & $\mathrm{~N}$ & 1,1400 & $\mathrm{G}$ & 1,0324 & $\mathrm{G}$ \\
\hline 12 & ULTJ & 1,0110 & $\mathrm{~N}$ & 0,9676 & $\mathrm{~N}$ & 1,0480 & $\mathrm{~N}$ & 0,9373 & $\mathrm{~N}$ & 1,0136 & $\mathrm{~N}$ \\
\hline
\end{tabular}

(Sumber: olah data 2020)

\section{Gross Margin Index (GMI)}

Dari hasil perhitungan Index diketahui hasil dari GMI dan penentuan kategori dijelaskan dalam tabel berikut:

Tabel 3. Hasil Perhitungan GMI dan Kategori Perusahaan

\begin{tabular}{|c|c|c|c|c|c|c|c|c|c|c|c|}
\hline \multirow{2}{*}{$\begin{array}{l}\mathbf{N} \\
\mathbf{0}\end{array}$} & \multirow{2}{*}{ Kode } & \multicolumn{2}{|c|}{2015} & \multicolumn{2}{|c|}{2016} & \multicolumn{2}{|c|}{2017} & \multicolumn{2}{|c|}{2018} & \multicolumn{2}{|c|}{2019} \\
\hline & & GMI & Kategori & GMI & Kategori & GMI & Kategori & GMI & Kategori & GMI & Kategori \\
\hline 1 & AISA & 0,0956 & $\mathrm{~N}$ & 0,8240 & $\mathrm{~N}$ & 2,0206 & $\mathrm{M}$ & 0,4448 & $\mathrm{~N}$ & 0,9854 & $\mathrm{~N}$ \\
\hline 2 & ALTO & 1,2607 & $M$ & 0,9872 & $\mathrm{~N}$ & 1,8905 & $M$ & 1,6061 & $M$ & 0,8022 & $\mathrm{~N}$ \\
\hline 3 & CEKA & 0,7050 & $\mathrm{~N}$ & 0,8114 & $\mathrm{~N}$ & 1,5828 & $\mathrm{M}$ & 0,8833 & $\mathrm{~N}$ & 0,6457 & $\mathrm{~N}$ \\
\hline 4 & DLTA & 0,9864 & $\mathrm{~N}$ & 0,4247 & $\mathrm{~N}$ & 0,9447 & $\mathrm{~N}$ & 1,0130 & $\mathrm{~N}$ & 1,0110 & $\mathrm{~N}$ \\
\hline 5 & ICBP & 0,8903 & $\mathrm{~N}$ & 0,9674 & $\mathrm{~N}$ & 1,0086 & $\mathrm{~N}$ & 0,9727 & $\mathrm{~N}$ & 0,9376 & $\mathrm{~N}$ \\
\hline 6 & INDF & 0,9998 & $\mathrm{~N}$ & 0,9286 & $\mathrm{~N}$ & 1,0248 & G & 1,0279 & G & 0,9285 & $\mathrm{~N}$ \\
\hline 7 & MLBI & 1,0435 & $\mathrm{G}$ & 0,8799 & $\mathrm{~N}$ & 0,9821 & $\mathrm{~N}$ & 1,0840 & $\mathrm{G}$ & 1,0041 & $\mathrm{~N}$ \\
\hline 8 & MYOR & 0,6316 & $\mathrm{~N}$ & 1,0609 & G & 1,1174 & G & 0,8990 & $\mathrm{~N}$ & 0,8404 & $\mathrm{~N}$ \\
\hline 9 & ROTI & 0,9026 & $\mathrm{~N}$ & 1,0295 & $\mathrm{G}$ & 0,9826 & $\mathrm{~N}$ & 0,9734 & $\mathrm{~N}$ & 0,9732 & $\mathrm{~N}$ \\
\hline 10 & SKLT & 0,9193 & $\mathrm{~N}$ & 0,9595 & $\mathrm{~N}$ & 0,9923 & $\mathrm{~N}$ & 1,0135 & $\mathrm{~N}$ & 1,0117 & $\mathrm{~N}$ \\
\hline 11 & STTP & 0,8976 & $\mathrm{~N}$ & 1,0009 & $\mathrm{~N}$ & 0,9622 & $\mathrm{~N}$ & 0,9905 & $\mathrm{~N}$ & 0,8079 & $\mathrm{~N}$ \\
\hline 12 & ULTJ & 0,7603 & $\mathrm{~N}$ & 0,9028 & $\mathrm{~N}$ & 0,9329 & $\mathrm{~N}$ & 1,0451 & $\mathrm{G}$ & 0,9495 & $\mathrm{~N}$ \\
\hline
\end{tabular}

(Sumber: olah data 2020) 


\section{JURNAL AKUNTANSI, Vol. 10, No. 1, April (2021)}

\section{Asset Quality Index (AQI)}

Dari hasil perhitungan Index diketahui hasil dari AQI dan penentuan kategori dijelaskan dalam tabel berikut:

Tabel 4. Hasil Perhitungan AQI dan Kategori Perusahaan

\begin{tabular}{|c|c|c|c|c|c|c|c|c|c|c|c|}
\hline \multirow{2}{*}{ No } & \multirow{2}{*}{ Kode } & \multicolumn{2}{|c|}{2015} & \multicolumn{2}{c}{$\mathbf{2 0 1 6}$} & \multicolumn{2}{c|}{$\mathbf{2 0 1 7}$} & \multicolumn{2}{c|}{2018} & \multicolumn{2}{c|}{2019} \\
\cline { 3 - 13 } & & AQI & Kategori & AQI & Kategori & AQI & Kategori & AQI & Kategori & AQI & Kategori \\
\hline 1 & AISA & 1,1664 & $\mathrm{G}$ & 0,3048 & $\mathrm{~N}$ & 1,4901 & $\mathrm{M}$ & 1,2053 & $\mathrm{G}$ & 1,0385 & $\mathrm{~N}$ \\
\hline 2 & ALTO & 3,9184 & $\mathrm{M}$ & 3,4583 & $\mathrm{M}$ & $-1,3282$ & $\mathrm{~N}$ & $-0,2132$ & $\mathrm{~N}$ & 1,0948 & $\mathrm{G}$ \\
\hline 3 & CEKA & 1,1007 & $\mathrm{G}$ & $-8,2234$ & $\mathrm{~N}$ & 0,2964 & $\mathrm{~N}$ & 3,5960 & $\mathrm{M}$ & 1,3542 & $\mathrm{M}$ \\
\hline 4 & DLTA & 1,1663 & $\mathrm{G}$ & $-8,6164$ & $\mathrm{~N}$ & 0,9583 & $\mathrm{~N}$ & $-0,1307$ & $\mathrm{~N}$ & 1,0433 & $\mathrm{G}$ \\
\hline 5 & ICBP & 1,0173 & $\mathrm{~N}$ & 0,9453 & $\mathrm{~N}$ & 1,0175 & $\mathrm{~N}$ & 1,2636 & $\mathrm{M}$ & 1,0035 & $\mathrm{~N}$ \\
\hline 6 & INDF & 0,9713 & $\mathrm{~N}$ & 1,2843 & $\mathrm{M}$ & 0,8715 & $\mathrm{~N}$ & 0,7418 & $\mathrm{~N}$ & 1,0442 & $\mathrm{G}$ \\
\hline 7 & MLBI & 1,3356 & $\mathrm{M}$ & 0,7084 & $\mathrm{~N}$ & 0,6544 & $\mathrm{~N}$ & 1,7146 & $\mathrm{M}$ & 1,2779 & $\mathrm{M}$ \\
\hline 8 & MYOR & 0,5231 & $\mathrm{~N}$ & 2,4110 & $\mathrm{M}$ & 0,6779 & $\mathrm{~N}$ & 2,2984 & $\mathrm{M}$ & 2,1389 & $\mathrm{M}$ \\
\hline 9 & ROTI & 1,3375 & $\mathrm{M}$ & 1,6425 & $\mathrm{M}$ & 1,2353 & $\mathrm{G}$ & 1,2457 & $\mathrm{G}$ & 0,8494 & $\mathrm{~N}$ \\
\hline 10 & SKLT & 1,0105 & $\mathrm{~N}$ & 0,7848 & $\mathrm{~N}$ & 1,1163 & $\mathrm{G}$ & 0,9995 & $\mathrm{~N}$ & 0,7320 & $\mathrm{~N}$ \\
\hline 11 & STTP & 0,8719 & $\mathrm{~N}$ & 6,7165 & $\mathrm{M}$ & 0,8660 & $\mathrm{~N}$ & 0,9418 & $\mathrm{~N}$ & 1,9006 & $\mathrm{M}$ \\
\hline 12 & ULTJ & 0,8331 & $\mathrm{~N}$ & 0,9762 & $\mathrm{~N}$ & 1,0411 & $\mathrm{G}$ & 2,9772 & $\mathrm{M}$ & 0,8574 & $\mathrm{~N}$ \\
\hline
\end{tabular}

(Sumber: olah data 2020)

\section{Sales Growth Index (SGI)}

Dari hasil perhitungan Index diketahui hasil dari SGI dan penentuan kategori dijelaskan dalam tabel berikut:

Tabel 5. Hasil Perhitungan SGI dan Kategori Perusahaan

\begin{tabular}{|c|c|c|c|c|c|c|c|c|c|c|c|}
\hline \multirow{2}{*}{ No } & \multirow{2}{*}{ Kode } & \multicolumn{2}{|c|}{2015} & \multicolumn{2}{c}{$\mathbf{2 0 1 6}$} & \multicolumn{2}{c|}{2017} & \multicolumn{2}{c|}{2018} & \multicolumn{2}{c|}{2019} \\
\cline { 3 - 13 } & & SGI & Kategori & SGI & Kategori & SGI & Kategori & SGI & Kategori & SGI & Kategori \\
\hline 1 & AISA & 1,1694 & $\mathrm{G}$ & 1,0890 & $\mathrm{~N}$ & 0,7517 & $\mathrm{~N}$ & 0,3964 & $\mathrm{~N}$ & 0,8117 & $\mathrm{~N}$ \\
\hline 2 & ALTO & 0,9079 & $\mathrm{~N}$ & 0,9824 & $\mathrm{~N}$ & 0,8842 & $\mathrm{~N}$ & 1,1226 & $\mathrm{~N}$ & 1,1689 & $\mathrm{G}$ \\
\hline 3 & CEKA & 0,9416 & $\mathrm{~N}$ & 1,1807 & $\mathrm{G}$ & 1,0346 & $\mathrm{~N}$ & 0,8524 & $\mathrm{~N}$ & 0,8599 & $\mathrm{~N}$ \\
\hline 4 & DLTA & 0,7450 & $\mathrm{~N}$ & 0,4926 & $\mathrm{~N}$ & 1,0030 & $\mathrm{~N}$ & 1,1488 & $\mathrm{G}$ & 0,9262 & $\mathrm{~N}$ \\
\hline 5 & ICBP & 1,0572 & $\mathrm{~N}$ & 1,0830 & $\mathrm{~N}$ & 1,0358 & $\mathrm{~N}$ & 1,0788 & $\mathrm{~N}$ & 1,1011 & $\mathrm{~N}$ \\
\hline 6 & INDF & 1,0074 & $\mathrm{~N}$ & 1,0405 & $\mathrm{~N}$ & 1,0529 & $\mathrm{~N}$ & 1,0457 & $\mathrm{~N}$ & 1,0436 & $\mathrm{~N}$ \\
\hline 7 & MLBI & 0,9022 & $\mathrm{~N}$ & 1,2103 & $\mathrm{G}$ & 1,0387 & $\mathrm{~N}$ & 1,0546 & $\mathrm{~N}$ & 1,0382 & $\mathrm{~N}$ \\
\hline 8 & MYOR & 1,0458 & $\mathrm{~N}$ & 1,2383 & $\mathrm{G}$ & 1,1344 & $\mathrm{~N}$ & 1,1558 & $\mathrm{G}$ & 1,0401 & $\mathrm{~N}$ \\
\hline 9 & ROTI & 1,1565 & $\mathrm{G}$ & 1,1598 & $\mathrm{G}$ & 0,9878 & $\mathrm{~N}$ & 1,1106 & $\mathrm{~N}$ & 1,2062 & $\mathrm{G}$ \\
\hline 10 & SKLT & 1,0935 & $\mathrm{~N}$ & 1,1191 & $\mathrm{~N}$ & 1,0963 & $\mathrm{~N}$ & 1,1431 & $\mathrm{G}$ & 1,2259 & $\mathrm{G}$ \\
\hline 11 & STTP & 1,1722 & $\mathrm{G}$ & 1,0333 & $\mathrm{~N}$ & 1,0747 & $\mathrm{~N}$ & 1,0005 & $\mathrm{~N}$ & 1,2425 & $\mathrm{G}$ \\
\hline 12 & ULTJ & 1,1218 & $\mathrm{~N}$ & 1,0665 & $\mathrm{~N}$ & 1,0413 & $\mathrm{~N}$ & 1,1216 & $\mathrm{~N}$ & 1,1404 & $\mathrm{G}$ \\
\hline
\end{tabular}

(Sumber: olah data 2020) 


\section{JURNAL AKUNTANSI, Vol. 10, No. 1, April (2021)}

\section{Depreciation Index (DEPI)}

Tabel 6. Indeks Parameter Depreciation Index (DEPI)

\begin{tabular}{|c|l|l|}
\hline No & \multicolumn{1}{|c|}{ Indeks } & \multicolumn{1}{|c|}{ Keterangan } \\
\hline 1 & $\leq 1,001 \quad$ Non Manipulators \\
\hline 2 & $1,001<$ index $<1,077$ & Grey Company \\
\hline 3 & $\geq 1,077$ & Manipulators \\
\hline
\end{tabular}

(Sumber: Beneish Ratio Index, 1999)

Dari hasil perhitungan Index diketahui hasil dari DEPI dan penentuan kategori dijelaskan dalam tabel berikut:

Tabel 7. Hasil Perhitungan DEPI dan Kategori Perusahaan

\begin{tabular}{|c|c|c|c|c|c|c|c|c|c|c|c|}
\hline \multirow{2}{*}{ No } & \multirow{2}{*}{ Kode } & \multicolumn{2}{|c|}{2015} & \multicolumn{2}{|c|}{2016} & \multicolumn{2}{c|}{2017} & \multicolumn{2}{c|}{2018} & \multicolumn{2}{c|}{2019} \\
\hline & DEPI & Kategori & DEPI & Kategori & DEPI & Kategori & DEPI & Kategori & DEPI & Kategori \\
\hline 1 & AISA & 0,9372 & $\mathrm{~N}$ & 0,9628 & $\mathrm{~N}$ & 0,5770 & $\mathrm{~N}$ & 0,1425 & $\mathrm{~N}$ & 0,8748 & $\mathrm{~N}$ \\
\hline 2 & ALTO & 1,0120 & $\mathrm{G}$ & 1,3633 & $\mathrm{M}$ & 1,3801 & $\mathrm{M}$ & 0,8760 & $\mathrm{~N}$ & 0,9986 & $\mathrm{~N}$ \\
\hline 3 & CEKA & 1,0294 & $\mathrm{G}$ & 1,3073 & $\mathrm{M}$ & 0,8463 & $\mathrm{~N}$ & 0,1691 & $\mathrm{~N}$ & 1,0664 & $\mathrm{G}$ \\
\hline 4 & DLTA & 1,0065 & $\mathrm{G}$ & 3,8217 & $\mathrm{M}$ & 1,0592 & $\mathrm{G}$ & 0,2437 & $\mathrm{~N}$ & 0,9279 & $\mathrm{~N}$ \\
\hline 5 & ICBP & 1,0553 & $\mathrm{G}$ & 0,9854 & $\mathrm{~N}$ & 1,0202 & $\mathrm{G}$ & 1,0577 & $\mathrm{G}$ & 0,8749 & $\mathrm{~N}$ \\
\hline 6 & INDF & 1,3171 & $\mathrm{M}$ & 0,7789 & $\mathrm{~N}$ & 1,1324 & $\mathrm{M}$ & 1,0770 & $\mathrm{G}$ & 0,9493 & $\mathrm{~N}$ \\
\hline 7 & MLBI & 0,9065 & $\mathrm{~N}$ & 1,0037 & $\mathrm{G}$ & 0,9303 & $\mathrm{~N}$ & 1,1615 & $\mathrm{M}$ & 0,8980 & $\mathrm{~N}$ \\
\hline 8 & MYOR & 1,0158 & $\mathrm{G}$ & 0,0475 & $\mathrm{~N}$ & 0,9877 & $\mathrm{~N}$ & 12,5061 & $\mathrm{M}$ & 0,9143 & $\mathrm{~N}$ \\
\hline 9 & ROTI & 0,9853 & $\mathrm{~N}$ & 1,0466 & $\mathrm{G}$ & 1,0509 & $\mathrm{G}$ & 0,9440 & $\mathrm{~N}$ & 0,9512 & $\mathrm{~N}$ \\
\hline 10 & SKLT & 1,3019 & $\mathrm{M}$ & 1,8720 & $\mathrm{M}$ & 0,9501 & $\mathrm{~N}$ & 0,9236 & $\mathrm{~N}$ & 0,9781 & $\mathrm{~N}$ \\
\hline 11 & STTP & 1,0241 & $\mathrm{G}$ & 0,4190 & $\mathrm{~N}$ & 0,8045 & $\mathrm{~N}$ & 0,8942 & $\mathrm{~N}$ & 1,0705 & $\mathrm{G}$ \\
\hline 12 & ULTJ & 1,5101 & $\mathrm{M}$ & 0,0671 & $\mathrm{~N}$ & 1,3148 & $\mathrm{M}$ & 1,0715 & $\mathrm{G}$ & 1,0607 & $\mathrm{G}$ \\
\hline
\end{tabular}

(Sumber: olah data 2020) 


\section{Sales and General Administration Expenses Index (SGAI)}

Dari hasil perhitungan Index diketahui hasil dari SGAI dan penentuan kategori dijelaskan dalam tabel berikut:

Tabel 8. Hasil Perhitungan SGAI dan Kategori Perusahaan

\begin{tabular}{|c|c|c|c|c|c|c|c|c|c|c|c|}
\hline \multirow{2}{*}{ No } & \multirow{2}{*}{ Kode } & \multicolumn{2}{|c|}{2015} & \multicolumn{2}{c|}{2016} & \multicolumn{2}{c|}{2017} & \multicolumn{2}{|c|}{2018} & \multicolumn{2}{c|}{2019} \\
\cline { 3 - 11 } & & SGAI & Kategori & SGAI & Kategori & SGAI & Kategori & SGAI & Kategori & SGAI & Kategori \\
\hline 1 & AISA & 1,2340 & $\mathrm{M}$ & 2,7909 & $\mathrm{M}$ & 1,8269 & $\mathrm{M}$ & 1,5534 & $\mathrm{M}$ & 0,8628 & $\mathrm{~N}$ \\
\hline 2 & ALTO & 0,9640 & $\mathrm{~N}$ & 0,7775 & $\mathrm{~N}$ & 1,4177 & $\mathrm{M}$ & 0,6129 & $\mathrm{~N}$ & 0,8247 & $\mathrm{~N}$ \\
\hline 3 & CEKA & 1,0252 & $\mathrm{~N}$ & 0,9471 & $\mathrm{~N}$ & 1,0427 & $\mathrm{G}$ & 1,3281 & $\mathrm{M}$ & 0,7739 & $\mathrm{~N}$ \\
\hline 4 & DLTA & 1,2403 & $\mathrm{M}$ & 2,0872 & $\mathrm{M}$ & 0,9800 & $\mathrm{~N}$ & 0,9136 & $\mathrm{~N}$ & 0,9955 & $\mathrm{~N}$ \\
\hline 5 & ICBP & 1,0846 & $\mathrm{M}$ & 0,9429 & $\mathrm{~N}$ & 0,9404 & $\mathrm{~N}$ & 1,0595 & $\mathrm{M}$ & 0,9966 & $\mathrm{~N}$ \\
\hline 6 & INDF & 1,0159 & $\mathrm{~N}$ & 1,0245 & $\mathrm{~N}$ & 0,9704 & $\mathrm{~N}$ & 1,0389 & $\mathrm{~N}$ & 1,0287 & $\mathrm{~N}$ \\
\hline 7 & MLBI & 0,2437 & $\mathrm{~N}$ & 4,4404 & $\mathrm{M}$ & 0,8700 & $\mathrm{~N}$ & 0,7270 & $\mathrm{~N}$ & 1,0325 & $\mathrm{~N}$ \\
\hline 8 & MYOR & 1,3582 & $\mathrm{M}$ & 0,8938 & $\mathrm{~N}$ & 0,8574 & $\mathrm{~N}$ & 1,2967 & $\mathrm{M}$ & 1,2104 & $\mathrm{M}$ \\
\hline 9 & ROTI & 0,2636 & $\mathrm{~N}$ & 4,0653 & $\mathrm{M}$ & 1,2206 & $\mathrm{M}$ & 1,1012 & $\mathrm{M}$ & 0,9529 & $\mathrm{~N}$ \\
\hline 10 & SKLT & 0,4913 & $\mathrm{~N}$ & 2,3589 & $\mathrm{M}$ & 0,9867 & $\mathrm{~N}$ & 0,9527 & $\mathrm{~N}$ & 0,9287 & $\mathrm{~N}$ \\
\hline 11 & STTP & 0,3688 & $\mathrm{~N}$ & 3,2524 & $\mathrm{M}$ & 1,0031 & $\mathrm{~N}$ & 0,9772 & $\mathrm{~N}$ & 0,9543 & $\mathrm{~N}$ \\
\hline 12 & ULTJ & 0,1999 & $\mathrm{~N}$ & 5,2843 & $\mathrm{M}$ & 1,0733 & $\mathrm{M}$ & 1,0886 & $\mathrm{M}$ & 0,9264 & $\mathrm{~N}$ \\
\hline
\end{tabular}

(Sumber: olah data 2020)

\section{Leverage Index (LVGI)}

Dari hasil perhitungan Index diketahui hasil dari LVGI dan penentuan kategori dijelaskan dalam tabel berikut:

Tabel 9. Hasil Perhitungan LVGI dan Kategori Perusahaan

\begin{tabular}{|c|c|c|c|c|c|c|c|c|c|c|c|}
\hline \multirow{2}{*}{ No } & \multirow{2}{*}{ Kode } & \multicolumn{2}{|c}{2015} & \multicolumn{2}{c}{2016} & \multicolumn{2}{c|}{2017} & \multicolumn{2}{c|}{2018} & \multicolumn{2}{c|}{2019} \\
\cline { 3 - 13 } & & LVGI & Kategori & LVGI & Kategori & LVGI & Kategori & LVGI & Kategori & LVGI & Kategori \\
\hline 1 & AISA & 1,0967 & G & 0,9591 & $\mathrm{~N}$ & 1,1308 & $\mathrm{M}$ & 4,4104 & $\mathrm{M}$ & 1,0783 & $\mathrm{G}$ \\
\hline 2 & ALTO & 0,9998 & $\mathrm{~N}$ & 1,0295 & $\mathrm{~N}$ & 1,0592 & $\mathrm{G}$ & 1,0468 & $\mathrm{G}$ & 1,0058 & $\mathrm{~N}$ \\
\hline 3 & CEKA & 0,9793 & $\mathrm{~N}$ & 0,6627 & $\mathrm{~N}$ & 0,9317 & $\mathrm{~N}$ & 0,4680 & $\mathrm{~N}$ & 1,1423 & $\mathrm{M}$ \\
\hline 4 & DLTA & 0,7647 & $\mathrm{~N}$ & 0,8518 & $\mathrm{~N}$ & 0,9452 & $\mathrm{~N}$ & 1,0737 & $\mathrm{G}$ & 0,9482 & $\mathrm{~N}$ \\
\hline 5 & ICBP & 0,9179 & $\mathrm{~N}$ & 0,9395 & $\mathrm{~N}$ & 0,9926 & $\mathrm{~N}$ & 0,9498 & $\mathrm{~N}$ & 0,9166 & $\mathrm{~N}$ \\
\hline 6 & INDF & 0,9968 & $\mathrm{~N}$ & 0,8772 & $\mathrm{~N}$ & 1,0065 & $\mathrm{~N}$ & 1,0312 & $\mathrm{~N}$ & 0,9040 & $\mathrm{~N}$ \\
\hline 7 & MLBI & 0,8449 & $\mathrm{~N}$ & 1,0065 & $\mathrm{~N}$ & 0,9006 & $\mathrm{~N}$ & 1,0351 & $\mathrm{~N}$ & 1,0142 & $\mathrm{~N}$ \\
\hline 8 & MYOR & 0,8973 & $\mathrm{~N}$ & 0,9504 & $\mathrm{~N}$ & 0,9840 & $\mathrm{~N}$ & 1,0147 & $\mathrm{~N}$ & 0,9331 & $\mathrm{~N}$ \\
\hline 9 & ROTI & 1,0105 & $\mathrm{~N}$ & 0,9020 & $\mathrm{~N}$ & 0,7542 & $\mathrm{~N}$ & 0,8811 & $\mathrm{~N}$ & 1,0100 & $\mathrm{~N}$ \\
\hline 10 & SKLT & 1,0073 & $\mathrm{~N}$ & 0,8023 & $\mathrm{~N}$ & 1,0789 & $\mathrm{G}$ & 1,0570 & $\mathrm{G}$ & 0,9505 & $\mathrm{~N}$ \\
\hline 11 & STTP & 0,9118 & $\mathrm{~N}$ & 1,0539 & $\mathrm{G}$ & 0,8176 & $\mathrm{~N}$ & 0,9155 & $\mathrm{~N}$ & 0,6802 & $\mathrm{~N}$ \\
\hline 12 & ULTJ & 0,9492 & $\mathrm{~N}$ & 0,8435 & $\mathrm{~N}$ & 1,0660 & $\mathrm{G}$ & 0,7453 & $\mathrm{~N}$ & 1,0263 & $\mathrm{~N}$ \\
\hline
\end{tabular}

(Sumber: olah data 2020) 


\section{JURNAL AKUNTANSI, Vol. 10, No. 1, April (2021)}

\section{Total Accruels to Total Assets (TATA)}

Dari hasil perhitungan Index diketahui hasil dari TATA dan penentuan kategori dijelaskan dalam tabel berikut:

Tabel 10. Hasil Perhitungan TATA dan Kategori Perusahaan

\begin{tabular}{|c|c|r|c|c|c|c|c|c|c|c|c|}
\hline \multirow{2}{*}{ No } & \multirow{2}{*}{ Kode } & \multicolumn{2}{|c|}{$\mathbf{2 0 1 5}$} & \multicolumn{2}{c}{$\mathbf{2 0 1 6}$} & \multicolumn{2}{c|}{2017} & \multicolumn{2}{c|}{2018} & \multicolumn{2}{c|}{2019} \\
\cline { 3 - 14 } & & TATA & Kategor & TATA & Kategori & TATA & Kategori & TATA & Kategori & TATA & Kategori \\
\hline 1 & AISA & $-0,0028$ & $\mathrm{~N}$ & 0,0884 & $\mathrm{M}$ & $-0,0935$ & $\mathrm{~N}$ & $-2,9432$ & $\mathrm{~N}$ & $-0,1585$ & $\mathrm{~N}$ \\
\hline 2 & ALTO & 0,0181 & $\mathrm{~N}$ & 0,0065 & $\mathrm{~N}$ & $-0,0357$ & $\mathrm{~N}$ & $-0,0312$ & $\mathrm{~N}$ & $-0,0355$ & $\mathrm{~N}$ \\
\hline 3 & CEKA & $-0,0007$ & $\mathrm{~N}$ & 0,0999 & $\mathrm{M}$ & $-0,0344$ & $\mathrm{~N}$ & $-0,1287$ & $\mathrm{~N}$ & $-0,1281$ & $\mathrm{~N}$ \\
\hline 4 & DLTA & 0,0034 & $\mathrm{M}$ & 0,0561 & $\mathrm{M}$ & 0,0200 & $\mathrm{G}$ & 0,0648 & $\mathrm{M}$ & 0,0968 & $\mathrm{M}$ \\
\hline 5 & ICBP & 0,0191 & $\mathrm{G}$ & 0,0097 & $\mathrm{~N}$ & 0,0015 & $\mathrm{~N}$ & 0,0522 & $\mathrm{M}$ & 0,0001 & $\mathrm{~N}$ \\
\hline 6 & INDF & 0,0343 & $\mathrm{M}$ & 0,0135 & $\mathrm{~N}$ & 0,0255 & $\mathrm{G}$ & 0,0332 & $\mathrm{M}$ & $-0,0365$ & $\mathrm{~N}$ \\
\hline 7 & MLBI & $-0,1160$ & $\mathrm{~N}$ & 0,0315 & $\mathrm{M}$ & 0,1786 & $\mathrm{M}$ & $-0,0650$ & $\mathrm{~N}$ & $-0,0443$ & $\mathrm{~N}$ \\
\hline 8 & MYOR & $-0,0418$ & $\mathrm{~N}$ & 0,1281 & $\mathrm{M}$ & 0,0794 & $\mathrm{M}$ & 0,1233 & $\mathrm{M}$ & $-0,0069$ & $\mathrm{~N}$ \\
\hline 9 & ROTI & $-0,0376$ & $\mathrm{~N}$ & 0,0097 & $\mathrm{~N}$ & $-0,0249$ & $\mathrm{~N}$ & $-0,0231$ & $\mathrm{~N}$ & $-0,0262$ & $\mathrm{~N}$ \\
\hline 10 & SKLT & 0,0104 & $\mathrm{~N}$ & 0,0563 & $\mathrm{M}$ & 0,0615 & $\mathrm{M}$ & 0,0529 & $\mathrm{M}$ & 0,0327 & $\mathrm{M}$ \\
\hline 11 & STTP & $-0,0345$ & $\mathrm{~N}$ & 0,0215 & $\mathrm{G}$ & $-0,0054$ & $\mathrm{~N}$ & 0,0303 & $\mathrm{G}$ & 0,0372 & $\mathrm{M}$ \\
\hline 12 & ULTJ & 0,0066 & $\mathrm{~N}$ & 0,0259 & $\mathrm{G}$ & $-0,0218$ & $\mathrm{~N}$ & 0,0570 & $\mathrm{~N}$ & 0,0254 & $\mathrm{G}$ \\
\hline
\end{tabular}

(Sumber: olah data 2020)

Menentukan perusahaan tergolong manipulators atau non manipulators menurut kriteria penggolongan.

1. Perusahaan yang memiliki $\geq 3$ (tiga) indeks hitung yang sesuai dengan indeks parameter yang menyatakan Manipulators, tergolong ke dalam perusahaan Manipulators.

2. Perusahaan yang memiliki $\geq 3$ (tiga) indeks hitung yang sesuai dengan indeks parameter yang menyatakan Non Manipulators, tergolong ke dalam perusahaan Non Manipulators.

3. Perusahaan yang memiliki $\geq 3$ (tiga) indeks hitung yang sesuai dengan indeks parameter yang menyatakan grey, dan indeks hitung yang tidak memenuhi 2 (dua) kriteria penggolongan tersebut (Manipulators dan Non Manipulators) digolongkan perusahaan grey (Grey Company).

Berdasarkan hasil perhitungan 8 rasio index terhadap 12 perusahaan sampel maka dapat diketahui bahwa pada tahun 2015 tidak terdapat perusahaan yang dikategorikan sebagai Manipulator, terdapat 1 perusahaan yang dikategorikan Grey Company dan 11 perusahaan dikategorikan sebagai Non Manipulator. Tahun 2016 tidak terdapat perusahaan yang dikategorikan sebagai Manipulator, terdapat 4 perusahaan yang dikategorikan Grey Company dan 8 perusahaan dikategorikan sebagai Non Manipulator. Tahun 2017 tidak terdapat perusahaan yang dikategorikan sebagai Manipulator, terdapat 1 perusahaan yang dikategorikan sebagai Grey Company dan 11 perusahaan dikategorikan sebagai Non Manipulator. Tahun 2018 terdapat 1 perusahaan yang dikategorikan sebagai Manipulator, 1 perusahaan dikategorikan sebagai Grey Company dan 10 perusahaan dikategorikan sebagai Non Manipulator. Tahun 2019 tidak terdapat perusahaan yang dikategorikan sebagai Manipulator, terdapat 1 perusahaan yang dikategorikan sebagai Grey Company dan 11 perusahaan dikategorikan sebagai Non Manipulator. 


\section{JURNAL AKUNTANSI, Vol. 10, No. 1, April (2021)}

Perhitungan jumlah persentase dari perusahaan yang tergolong manipulators atau non manipulators.

1. Perusahaan Manipulator

Berikut hasil perhitungan persentase perusahaan yang tergolong manipulator:

Tabel 11. Perhitungan Persentase Perusahaan Manipulator

\begin{tabular}{|c|c|c|}
\hline Tahun & Perhitungan & Hasil \\
\hline 2015 & - & - \\
\hline 2016 & - & - \\
\hline 2017 & - & - \\
\hline 2018 & Manipulator $=\frac{1}{12} \times 100 \%$ & $8,33 \%$ \\
\hline 2019 & - & - \\
\hline
\end{tabular}

2. Perusahaan Non Manipulator

Berikut hasil perhitungan persentase perusahaan yang tergolong Non manipulator:

Tabel 12. Perhitungan Persentase Perusahaan Non Manipulator

\begin{tabular}{|c|c|c|}
\hline Tahun & Perhitungan & Hasil \\
\hline 2015 & Non Manipulator $=\frac{11}{12} \times 100 \%$ & $91,67 \%$ \\
\hline 2016 & Non Manipulator $=\frac{8}{12} \times 100 \%$ & $66,67 \%$ \\
\hline 2017 & Non Manipulator $=\frac{11}{12} \times 100 \%$ & $91,67 \%$ \\
\hline 2018 & Non Manipulator $=\frac{10}{12} \times 100 \%$ & $83,33 \%$ \\
\hline 2019 & Non Manipulator $=\frac{11}{12} \times 100 \%$ & $91,67 \%$ \\
\hline
\end{tabular}

3. Perusahaan Grey Company

Berikut hasil perhitungan persentase perusahaan yang tergolong Grey Companyr:

Tabel 13. Perhitungan Persentase Perusahaan Grey Company

\begin{tabular}{|c|c|c|}
\hline Tahun & Perhitungan & Hasil \\
\hline 2015 & Grey Company $=\frac{1}{12} \times 100 \%$ & $8,33 \%$ \\
\hline 2016 & Grey Company $=\frac{4}{12} \times 100 \%$ & $33,33 \%$ \\
\hline 2017 & Grey Company $=\frac{1}{12} \times 100 \%$ & $8,33 \%$ \\
\hline 2018 & Grey Company $=\frac{1}{12} \times 100 \%$ & $8,33 \%$ \\
\hline 2019 & Grey Company $=\frac{1}{12} \times 100 \%$ & $8,33 \%$ \\
\hline
\end{tabular}

\section{PEMBAHASAN}

1) Perusahaan yang Tergolong Manipulator

Menurut hasil analisis dengan beneish ratio index dari 12 perusahaan subsektor makanan dan minuman diketahui bahwa perusahaan yang tergolong manipulator pada tahun 2015 - 2019 hanya terdapat 1 perusahaan atau 8,33\% yaitu pada tahun 2018. Perusahaan yang melakukan kecurangan (fraud) terhadap laporan keuangannya dapat merugikan pihak-pihak pengguna laporan keuangan tersebut, karena laporan keuangan tersebut disajikan tidak sesuai 
dengan kenyataan yang ada. Kecurangan (fraud) yang dilakukan biasanya dengan melebihsajikan harta kekayaan dan keuntungan, sehingga menarik perhatian investor dan kreditor untuk menanamkan modal atau memberikan pinjaman kredit terhadap perusahaan tersebut (Efitasari, 2013).

\section{2) Perusahaan yang Tergolong Non Manipulator}

Menurut hasil analisis dengan beneish ratio index dari 12 perusahaan subsektor makanan dan minuman diketahui bahwa perusahaan yang tergolong non manipulator pada tahun 2015 sebanyak 11 perusahaan atau 91,67\%, tahun 2016 sebanyak 8 perusahaan atau 66,67\%, tahun 2017 sebanyak 11 perusahaan atau 91,67\%, tahun 2018 sebanyak 10 perusahaan atau 83,33\%, dan tahun 2019 sebanyak 11 perusahaan atau 91,67\%. Investor dan kreditor dapat meningkatkan kepercayaannya terhadap perusahaan-perusahaan yang masuk dalam kategori non manipulators, karena laporan keuangan yang mereka sampaikan tidak terindikasi adanya kecurangan (fraud), sehingga dapat mengurangi resiko tingkat pengembalian modal bagi investor dan resiko pinjaman yang tidak kembali bagi kreditor. Oleh karena itu, perusahaanperusahaan yang masuk dalam kategori non manipulators layak mendapatkan penghargaan (reward) dari pihak-pihak terkait atas komitmen mereka dalam melindungi kepentingan pengguna laporan keuangannya.

\section{3) Perusahaan yang Tergolong Grey Company}

Menurut hasil analisis dengan beneish ratio index dari 12 perusahaan subsektor makanan dan minuman diketahui bahwa perusahaan yang tergolong Grey Company pada tahun 2015 terdapat 1 perusahaan atau 8,33\%, tahun 2016 sebanyak 4 perusahaan atau 33,33\%, tahun 2017 hingga tahun 2019 terdapat 1 perusahaan atau 8,33\% yang tergolong Grey Company. Perusahaan ini tidak digolongkan sebagai perusahaan manipulators maupun non manipulators karena kriteria dari kedua kategori tidak terpenuhi. Untuk dikategorikan sebagai perusahaan yang tidak melakukan manipulasi terhadap laporan keuangan, indeks rasio dari perusahaan tersebut melebihi nilai ambang batas yang telah ditetapkan, sedangkan untuk dikategorikan sebagai perusahaan yang memanipulasi laporan keuangan, indeks rasio perusahaan tersebut belum melampaui nilai ambang batas. Kemungkinan terdapat usaha-usaha yang dilakukan perusahaan untuk memanipulasi laporan keuangannya namun tidak signifikan, sehingga perusahaan yang berada dalam kondisi ini masuk dalam kategori Grey atau Grey Company. Oleh karena itu, pihak-pihak yang terkait diharapkan berhati-hati dalam menggunakan informasi dari laporan keuangan perusahaan kategori ini, sebab di masa mendatang perusahaanperusahaan ini dapat masuk dalam kategori perusahaan manipulators. Tindakan sanksi juga belum diperlukan untuk perusahaan kategori ini, karena mereka belum terbukti melakukan kecurangan (fraud) yang berlebihan.

\section{PENUTUP \\ Simpulan}

Berdasarkan analisis dan pembahasan di muka maka dapat ditarik kesimpulan sebagai berikut: 1) Analisis indeks rasio menunjukkan bahwa Perusahaan Subsektor Makanan dan Minuman yang terdaftar di Bursa Efek Indonesia tahun 2015 - 2019 yang tergolong manipulator hanya terdapat 1 perusahaan atau 8,33\% yaitu pada tahun 2018. Perusahaan yang tergolong dalam kategori perusahaan Manipulators memiliki indikasi melakukan fraud (kecurangan) terhadap penyajian laporan keuangannya. 2) Analisis indeks rasio menunjukkan bahwa Perusahaan Subsektor Makanan dan Minuman yang terdaftar di Bursa Efek Indonesia yang tergolong non manipulator pada tahun 2015 sebanyak 11 perusahaan atau 91,67\%, tahun 2016 sebanyak 8 perusahaan atau 66,67\%, tahun 2017 sebanyak 11 perusahaan atau 91,67\%, tahun 2018 sebanyak 8 perusahaan atau 83,33\%, dan tahun 2019 sebanyak 11 perusahaan atau 91,67\%. Selama tahun 2015-2019 perusahaan subsektor makanan dan minuman yang tergolong 
sebagai non manipulator mengalami peningkatan dan penurunan (adanya fluktuasi). 3) Analisis indeks rasio menunjukkan bahwa Perusahaan Subsektor Makanan dan Minuman yang terdaftar di Bursa Efek Indonesia yang tergolong Grey Company pada tahun 2015 terdapat 1 perusahaan atau 8,33\%, tahun 2016 sebanyak 4 perusahaan atau 33,33\%, tahun 2017 hingga tahun 2019 terdapat 1 perusahaan atau 8,33\% yang tergolong Grey Company. Perusahaan ini tidak digolongkan sebagai manipulators atau non manipulators. Grey company memiliki indikasi melakukan kecurangan laporan keuangan namun dalam jumlah yang tidak signifikan.

\section{Saran}

Berdasarkan simpulan yang didapat serta keterbatasan penelitian yang ada, saran untuk penelitian selanjutnya diharapkan dapat memilih periode tahun pengamatan yang lebih panjang, memperluas sampel penelitian, sehingga tidak terbatas hanya pada satu sektor saja, dengan tujuan supaya hasil yang nantinya diperoleh akan lebih akurat sehingga dapat menggambarkan fenomena financial statement fraud. Selain itu, penelitian selanjutnya juga dapat menghitung tingkat signifikansi dari tiap variabel-variabel akuntansi, sehingga dapat diketahui mana variabel yang secara signifikan mampu membedakan antara perusahaan manipulators dan perusahaan non manipulators.

Bagi perusahaan, diharapkan tidak melakukan kecurangan (fraud) dalam peyajian laporan keuangaannya, karena hal itu dapat merugikan pengguna laporan keuangan tersebut. Bagi investor, calon investor, pemegang saham dan kreditur serta analisis pasar modal dalam mengambil keputusan untuk membeli saham, diharapkan dapat melakukan analisis dengan baik terhadap laporan keuangan ataupun mencari informasi tambahan di luar laporan keuangan tersebut.

\section{REFERENSI}

Ainul Fithriyah. 2018. Analisa Laporan Keuangan Sebagai Penilaian Kinerja Keuangan Perusahaan. Skripsi. Jurusan Manajemen Fakultas Ekonomi Universitas Islam Negri (UIN).

Apriani, Islami Putri. Et.Al. 2019. Analisis Pendeteksian Kecurangan Laporan Keuangan dengan Menggunakan Beneish Ratio Index. Jurnal Administrasi Bisnis (JAB). Vol 72, No 2.

Association of Certified Fraud Examiners. (2016). Report to the nations on occupational fraud and abuse. Association of Certified Fraud Examiners, 1-92.

Association of Certified Fraud Examiners.(2016). Survei Fraud Indonesia. Association Of Certified Fraud, Examiners, 1-62.

Christy, Yanuary Eka. 2018. Pendeteksian Kecurangan Laporan Keuangan dengan Beneish MScore pada Perusahaan Perbankan Terbuka. Jurnal Akuntansi Bisnis. Vol 16, No1.

Erna Septiani Dewi, Sudrajat, 2019. Pendeteksian Financial Statement Fraud dengan Menggunakan Beneish Ratio Index Pada Perusahaan Manufaktur yang terdaftar di Bursa Efek Indonesia.

Gumanti, Tatang. 2011. Manajemen investasi: Konsep, teori, dan Aplikasi. Jakarta: Mitra Wacana Media

Ikatan Akuntan Indonesia 2012. Pernyataan Standar Akuntansi Keuangan (PSAK) No.1 tentang Penyajian Laporan Keuangan. Revisi 2012.

Indarti. 2019. Analisis Beneish Ratio Index untuk Mendeteksi Fraudulent Financial Reporting pada Perusahaan Perbankan yang Terdaftar Di Bursa Efek Indonesia Periode 2015-2016. Jurnal Aplikasi Ekonomi, Akuntansi dan Bisnis. Vol 1, No 1. Hal 057-066.

Irsutami. Et.Al. 2020. Mendeteksi Kecurangan Laporan Keuangan Menggunakan Model Beneish. Journal of Applied Accounting and Taxation. Vol 5, No 1. 
Kurnianingsih, Heny Triastuti. Et.Al. 2019. Metode Beneish Ratio Index dalam Pendeteksian Financial Statement Fraud (Sudi Kasus Perusahaan Konsumsi di Bursa Efek Indonesia). Jurnal Riset Akuntansi Multiparadigma (JRAM). Vol 6, No 1.

Listiana Norbarani. 2012. Pendeteksian kecurangan laporan keuangan dengan analisis fraud triangle yang di adopsi dalam SAS no.99. Skripsi. Ekonomika dan bisnis universitas diponegoro.

Nasution, Maya Sandita. Et.Al. 2019. Pengaruh Fraud Pentagon Terhadap Kecurangan Laporan Keuangan (Studi Pada Perusahaan Manufaktur Sub Sektor Makanan Dan Minuman Yang Terdaftar Di Bursa Efek Indonesia Periode 2013-2017). Jurnal Aksara Public. Vol 3, No 3. Hal 153-165.

Normah Omar, Ridzuan Kunji Koya, Zuraidah Mohd Sanusi, Nur Aima Shafie, 2014. Financial Statement Fraud: A Case Examination Using Beneish Model and Ratio Analysis.

Sari Wulandari, 2018. Analisis Laporan Keuangan Untuk menilai kinerja keuangan perusahaan. Skripsi. Jurusan manajemen fakultas ekonomi universitas sanata dharma, yogyakarta.

Setyarini Santosa, Josep Ginting, 2019. Evaluasi Keakuratan Model Beneish M-Score sebagai alat deteksi Kecurangan Laporan Keuangan (Kasus Perusahaan Pada Otoritas jasa keuangan di Indonesia).

Suci Mawarni, 2016. Pengaruh fraud triangle terhadap kemungkinan kecurangan pelaporan keuangan. Skripsi. Jurusan akuntansi fakultas ekonomi dan bisnis universitas bengkul.

Suheni, Venny. Et.Al. 2020. Mendeteksi financial statement fraud dengan menggunakan Model Beneish M-score (studi pada perusahaan sektor manufaktur yang terdaftar di bursa efek Indonesia). Jurnal Akuntansi dan Ekonomi FE UN PGRI Kediri. Vol 5, No 2.

Swarna, Dian Dara. 2012. " Penerapan Akuntansi Forensik dan Audit Investigatif untuk Mendeteksi Fraud di Era digital". 